\title{
Benefits and Returns of Adopt-A-Park Programme in Kuala Lumpur
}

\author{
Jamalunlaili Abdullah¹, Raziah Ahmad² , Muhammad Hafiz Zainal² \\ ${ }^{1}$ Centre of Studies for Town and Regional Planning, 2,Centre of Studies for Landscape Architecture, \\ Faculty of Architecture, Planning and Surveying, \\ Universiti Teknologi MARA, Puncak Alam Campus, Selangor, Malaysia \\ jamal858@uitm.edu.my, razia841@uitm.edu.my, hafizzainal@uitm.edu.my \\ Tel of 1st Author: 0136722899
}

\begin{abstract}
A collaborative partnership between local authorities and corporate agencies in maintaining and managing urban public parks through the Adopt-APark Programme has become a standard approach throughout the United States and Europe. In the Malaysian context, this programme came into the limelight of the Kuala Lumpur City Hall (DBKL) practices via the Greener Kuala Lumpur initiatives. Between 2012 and 2018, fifteen corporate agencies have shown their proactive involvement through corporate social responsibility (CSR) to beautify and maintain the urban green spaces in Kuala Lumpur via the park adoption programme which helped Dewan Bandaraya Kuala Lumpur / KL City Hall (DBKL) to manage its public parks effectively despite the limited budget. This paper aims to examine the benefits and returns of the Adopt-A-Park Programme at the Laman @ Eco Sky and the Metropolis Park to DBKL, park users and park adopters. Park users' satisfaction and allocations spent by the corporate adopters are analysed descriptively. Results show that while DBKL saved about RM24 million of the maintenance cost, $94 \%$ of the adopted park users are satisfied with the quality of the park. This programme should include more parks, especially in low-income communities.
\end{abstract}

Keywords: Adopt-A-Park Programme, Adoption, Urban Park, Benefits and Returns

eISSN: 2398-4287 @ 2019. The Authors. Published for AMER ABRA cE-Bs by e-International Publishing House, Ltd., UK. This is an open access article under the CC BYNC-ND license (http://creativecommons.org/licenses/by-nc-nd/4.0). Peer-review under responsibility of AMER (Association of Malaysian Environment-Behaviour Researchers), ABRA (Association of Behavioural Researchers on Asians) and cE-Bs (Centre for Environment-Behaviour Studies), Faculty of Architecture, Planning \& Surveying, Universiti Teknologi MARA, Malaysia.

DOI: https://doi.org/10.21834/e-bpj.v4i12.1930

\subsection{Introduction}

Adopt-A-Park Programme has become a trendy approach of Corporate Social Responsibility (CSR) that shows tripartite partnerships among the local authorities, local residents and corporate agencies. Such a programme has commonly been practised in many big cities such as London and New York. In the context of Kuala Lumpur, the Park Adoption Programme has been promoted under the Greater Kuala Lumpur and Klang Valley's Greener KL Entry Point Projects (EPPs). This programme came into the limelight of the Kuala Lumpur City Hall (DBKL) practices via the Greener Kuala Lumpur initiatives. Between 2012 and 2018, fifteen corporate agencies have participated in the Adopt-A-Park Programme, which aims to beautify and maintain urban public parks in Kuala Lumpur using private funds.

While well maintained green lungs and pocket parks can be vibrant with the high-quality environment (Zhang, 2002; Wang \& Adolphe, 2012), it is also often associated with positive psychological effects for work environments ((Ose-land 2009; Jahncke et al. 2011). Although DBKL has embraced the trend of the greening of the cities, the cost of maintaining the urban public green spaces is also escalating. With limited budgets, big cities around the world are facing difficulties to maintain their parks and green areas and Kuala Lumpur is no exception (Wong, 2015).

Due to the limited yearly allocation, DBKL is often struggling to sustain its public parks. Adding to this, a sizeable coverage of urban park that requires a significant number of labourers to keep the park clean, safe and usable is also a challenge. Thus, the park adoption programme has been practised in Kuala Lumpur since 201. However, there is no analysis done so far about the efficiency and relevance

eISSN: 2398-4287 @ 2019. The Authors. Published for AMER ABRA cE-Bs by e-International Publishing House, Ltd., UK. This is an open access article under the CC BYNC-ND license (http://creativecommons.org/licenses/by-nc-nd/4.0/). Peer-review under responsibility of AMER (Association of Malaysian Environment-Behaviour Researchers), ABRA (Association of Behavioural Researchers on Asians) and cE-Bs (Centre for Environment-Behaviour Studies), Faculty of Architecture, Planning \& Surveying, Universiti Teknologi MARA, Malaysia. DOI: https://doi.org/10.21834/e-bpj.v4i12.1930 
of this programme in Malaysia and Kuala Lumpur, especially. Hence, this paper attempts to investigate the benefits and returns of the park adoption programme to DBKL and to the urban community.

\subsection{Literature Review}

\subsection{Government Plans and Policies}

Government plans and policies can provide insights and be translated into environmental and social sustainability to stimulate CSR programmes. The Economic Transformation Programme (ETP) was launched by the former Prime Minister, Dato' Sri Najib Razak in September 2010. It consists of six Strategic Reform Initiatives (SRIs) and 12 National Key Economic Areas (NKEAs). The NKEAs include various Entry Point Projects (EPPs) in numerous industries (PEMANDU, 2012). The Greater Kuala Lumpur, which is part of the 12 National Key Economic Areas (NKEAs) of the ETP has been outlined to transform the capital city of Kuala Lumpur into a vibrant, livable and prosperous metropolitan (Yau et al., 2016).

\subsection{Corporate Social Responsibility (CSR)}

The concept of CSR was pioneered by Howard. R Bowen who was published in his 1953 book called Social Responsibilities of Businessman. According to Kanji and Agrawal (2019), Bowen's idea implies that businesses are "vital centres of power and decision making and that the actions of the firms touch the lives of citizens at many points". Bowen's underlying concept of CSR has grown exponentially, yet gradually becoming a global trend (Lu and Castka, 2009; Mohd. Nasir et al. 2015). In the Malaysian context, this trend is also apparent as evidenced in the works of Rashid and Ibrahim (2002), Ramasamy and Ting (2004), and Thompson and Zakaria, (2004). The CSR programmes that Malaysia's corporate agencies undertake in the park adoption programmes are found in the local newspaper reports (Nathan, 2015; Kathy. B, 2019) as well as in the property news report (Wan Fauzi, 2015; Naza, 2017).

\subsection{Park Adoption}

The concept of park adoption connotes a link between policy and practice (Race \& Curtis, 2007; Jepson \& Whittaker, 2002) and acts as a motivation for preservation and conservation (Burnett \& Harrington, 1994). Although park adoption has commonly been practised in many big cities around the globe, this topic is still under-researched in the academic arena, resulting in relatively scarce materials for references. In the Malaysian context, the lack of literature on the idea behind park adoption is no exception. Nevertheless, the growing interest in the CSR programmes that often incorporated park adoption has brought this topic into the limelight of the Malaysian newspapers (Nair, 2015; Nathan, 2015; Bavani.M, 2017) and property press release (EcoWorld, 2015; Naza Press, 2017).

\subsection{Methodology}

\subsection{Study Area}

Greener Kuala Lumpur was initiated by Kuala Lumpur City Hall (DBKL). Thus, the Park Adoption Programme under Greener Kuala Lumpur has been run within its jurisdiction. The programme had managed to obtain the involvement from 10 corporate organizations from the year 2012 to 2018, who had helped in developing and maintaining several green areas or spaces in Kuala Lumpur. Table 1.0 shows a list of 10 Park Adoption in Kuala Lumpur. From the ten green spaces or areas, two were selected as the case studies for this research which are: 1) Laman @ EcoSky - adopted by EcoWorld which is situated at Jalan Ipoh, Kuala Lumpur; and 2) Metropolitan Park - adopted by NAZA TTDI and located at Plot 8, KL Metropolis, Mont Kiara.

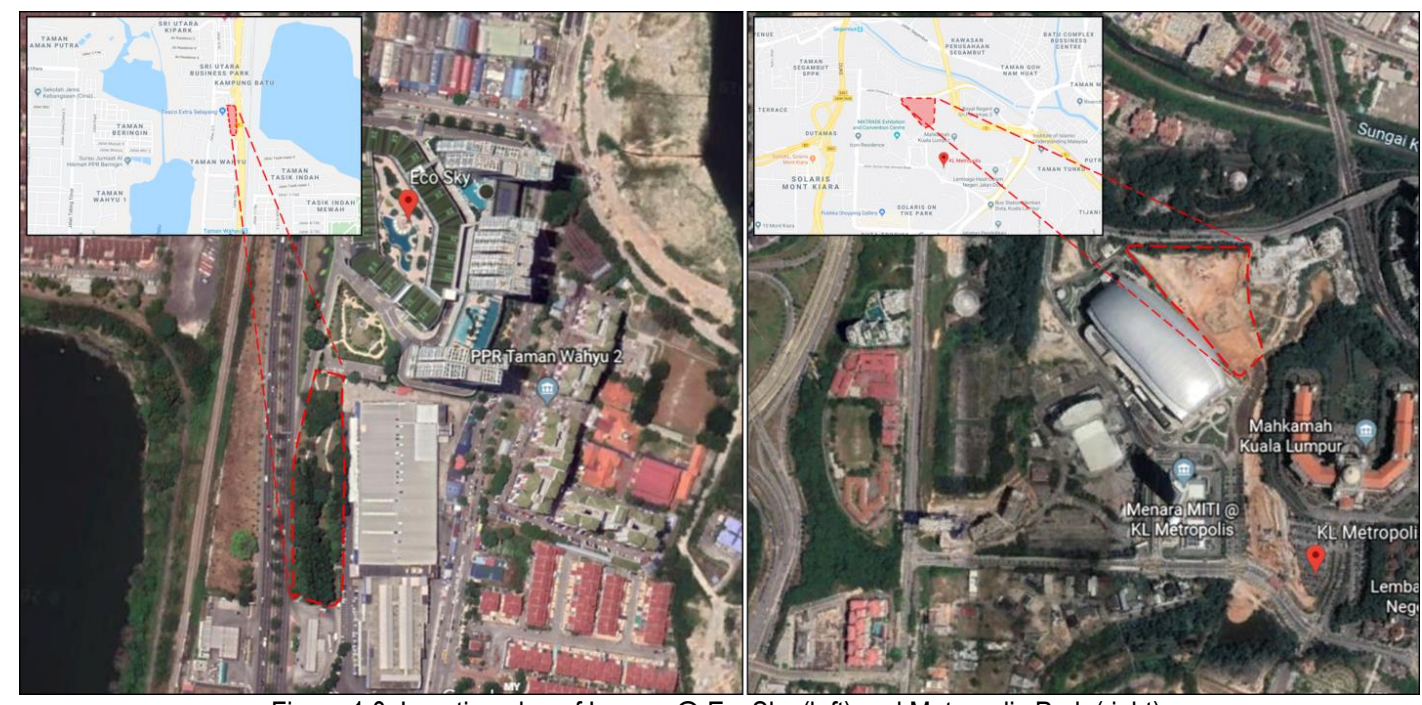

Figure 1.0: Location plan of Laman @ EcoSky (left) and Metropolis Park (right). 


\subsection{Data collection}

This research uses secondary data obtained from DBKL as well as local newspapers and property news reports on Park Adoption Programme. The former facilitates statistical data of the Laman @ EcoSky park users while the latter provides details information on sponsorship of the adopters.

Due to lack of published academic researches on park adoption in Malaysia, local newspapers and property news reports are used and analysed. As shown in Table 2.0, a total of 18 newspaper articles and property news reports published between 2012-2019 that highlight the park adoption programme at Laman @ EcoSky and Kuala Lumpur Metropolis Park are analyzed. Six attributes are established from these sources of data: Details information of sponsorship sizes of the parks, allocations of sponsorship, public-private partnership, objectives of park adoption and benefits and returns (Table 1.0).

Only two adopted parks are discussed in this study, as they are the only parks that are widely reported in the media, thus enabling the analysis of the information. Most of the information, especially on the budget and monetary are confidential, causing reliance on information reported in the newspaper and property news report. The data on people's usage and visit, perception and satisfaction are only available on one adopted park, Laman @ EcoSky as the project is already completed and enabled DBKL to conduct the survey there. KL Metropolis Park is not completed yet.

\subsection{Data Analysis}

There are two types of analyses conducted in this research. The first is the newspaper content analysis, and the second is the survey questionnaire data provided by DBKL - the data obtained are analysed descriptively. Table 1.0 shows a summary of the analysis of the six attributes. Survey questionnaire obtained from DBKL provide insights into local residents' response on their awareness, preference and also the perception of the programme. The statistics from the survey are used to assess the local communities' reasons for visiting, time spent at the park and their satisfaction levels.

\begin{tabular}{|c|c|c|c|c|c|c|c|c|}
\hline \multirow[t]{2}{*}{ No. } & \multirow[t]{2}{*}{ Sponsored by } & \multirow[t]{2}{*}{ Location } & \multirow{2}{*}{$\begin{array}{l}\text { Location of } \\
\text { Mini Park }\end{array}$} & \multicolumn{3}{|c|}{ Sponsorship Details } & \multirow[t]{2}{*}{ Size (Acre) } & \multirow[t]{2}{*}{ Remark } \\
\hline & & & & Start & End & $\begin{array}{l}\text { Duration } \\
\text { (Year) }\end{array}$ & & \\
\hline \multirow[t]{2}{*}{1} & $\begin{array}{l}\text { Standard } \\
\text { Chartered Bank } \\
\text { (M) Berhad }\end{array}$ & $\begin{array}{l}\text { Jalan P. Ramlee, } \\
\text { Kuala Lumpur }\end{array}$ & $\begin{array}{l}\text { Laman } \\
\text { Standard } \\
\text { Chartered } \\
\text { Kuala Lumpur }\end{array}$ & 4 July 2012 & $\begin{array}{l}3^{\text {3rd }} \text { July } \\
2017\end{array}$ & $5+2$ & 0.94 & $\begin{array}{l}\text { Completed } \\
\text { Termination of KL Adoption } \\
\text { Agreement }\end{array}$ \\
\hline & $\begin{array}{l}\text { Eco Sky } \\
\text { Development } \\
\text { Sdn. Bhd. }\end{array}$ & $\begin{array}{l}\text { Jalan Ipoh, Kuala } \\
\text { Lumpur }\end{array}$ & $\begin{array}{l}\text { LAMAN @ } \\
\text { ECO SKY }\end{array}$ & 1st April 2015 & $\begin{array}{l}31^{\text {st }} \\
\text { March } \\
2018\end{array}$ & $3+2$ & 2.73 & $\begin{array}{l}\text { Completed }(2015) \text {. } \\
\text { Continuation of Agreement } \\
\text { letter received on } 8^{\text {th }} \text { May } \\
\text { 2018. Continuation for another } \\
\text { one year until } 31 \text { March } 2019\end{array}$ \\
\hline 3 & $\begin{array}{l}\text { Veritas } \\
\text { Landscape Sdn. } \\
\text { Bhd. }\end{array}$ & $\begin{array}{l}\text { Persimpangan } \\
\text { Jalan } \\
\text { Ampang/Jalan P. } \\
\text { Ramlee, Kuala } \\
\text { Lumpur }\end{array}$ & $\begin{array}{l}\text { LAMAN @ } \\
\text { VERITAS }\end{array}$ & $1^{\text {st }}$ April 2015 & $\begin{array}{l}31^{\text {st }} \\
\text { March } \\
2017\end{array}$ & $2+2$ & 0.02 & Completed (2015) \\
\hline 4 & $\begin{array}{l}\text { JL99 } \\
\text { Development } \\
\text { Sdn. Bhd. }\end{array}$ & $\begin{array}{l}\text { Lot } 80241 \text {, Off } \\
\text { Jalan Ipoh, } \\
\text { Mukim Batu, } \\
\text { Tasik Sri } \\
\text { Kuarni, } \\
\text { Kuala Lumpur }\end{array}$ & $\begin{array}{l}\text { Taman Tasik } \\
\text { Sri Murni }\end{array}$ & $15^{\text {th }}$ July 2016 & $\begin{array}{l}14^{\text {th }} \text { July } \\
2021\end{array}$ & $5+5$ & $\begin{array}{l}20.0 \text { acre }(+ \\
\text { retention } \\
\text { pond }(16.0 \\
\text { acre })\end{array}$ & Completed (2016) \\
\hline 5 & $\begin{array}{l}\text { Tesco (M) Sdn } \\
\text { Bhd }\end{array}$ & $\begin{array}{l}\text { Opposite } \\
\text { Hypermarket } \\
\text { Tesco Kepong } \\
\text { Village, Bandar } \\
\text { Menjalara }\end{array}$ & N.A & N.A & N.A & 2 & 0.7 & $\begin{array}{l}\text { Completed (2016). Stamping } \\
\text { Process by Tesco (M) Sdn. } \\
\text { Bhd. }\end{array}$ \\
\hline 6 & $\begin{array}{l}\text { Bukit Tunku } \\
\text { Resident } \\
\text { Association }\end{array}$ & $\begin{array}{l}\text { Bulatan Bukit } \\
\text { Tunku }\end{array}$ & Taman BTRA & N.A & N.A & 5 & N.A & $\begin{array}{l}\text { Completed. Stamping } \\
\text { agreement by Bukit Tunku } \\
\text { Resident Association (2016) }\end{array}$ \\
\hline 7 & $\begin{array}{l}\text { NAZA TTDI } \\
\text { Sdn. Bhd. }\end{array}$ & $\begin{array}{l}\text { Plot 8, KL } \\
\text { Metropolis City }\end{array}$ & $\begin{array}{l}\text { Letter to DB: } \\
28.11 .2016\end{array}$ & N.A & N.A & $5+2$ & 5 & $\begin{array}{l}\text { The groundbreaking } \\
\text { ceremony was held on } 3^{\text {rd }} \text { April } \\
\text { 2017. Draft of the agreement } \\
\text { has been sent to Naza TTDI to } \\
\text { be improvised. Duration of the } \\
\text { agreement has been agreed. }\end{array}$ \\
\hline 8 & $\begin{array}{l}\text { Dynamic } \\
\text { Property } \\
\text { Management }\end{array}$ & Jalan Kamunting & $\begin{array}{l}\text { Laman } \\
\text { Kamunting @ } \\
\text { Stripes Hotel }\end{array}$ & No information & $\begin{array}{l}\text { No } \\
\text { informati } \\
\text { on }\end{array}$ & $5+2$ & $271.16 \mathrm{~m}^{2}$ & $\begin{array}{l}\text { In the process of improvising } \\
\text { the } 2^{\text {nd }} \text { agreement draft by } \\
\text { Dynamic } \quad \text { Property } \\
\text { Management. Duration of the } \\
\text { agreement has been agreed. }\end{array}$ \\
\hline
\end{tabular}




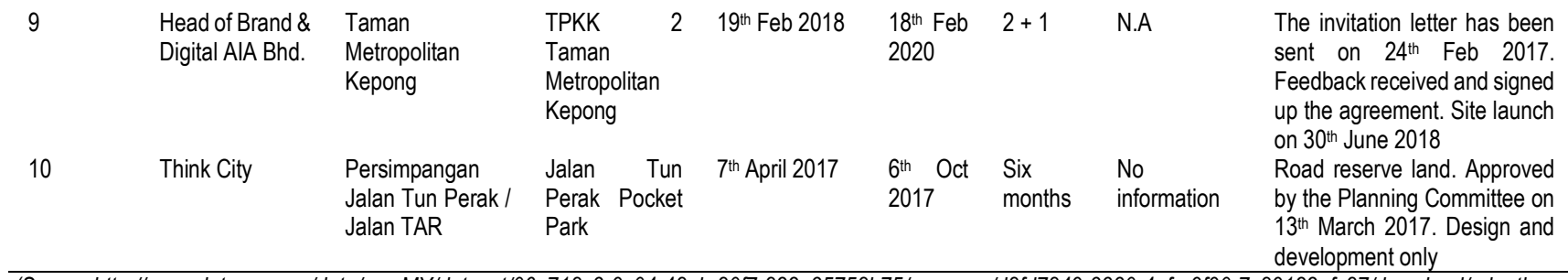

(Source:http://www.data.gov.my/data/ms_MY/dataset/06e718c3-9c04-48ab-80f7-822a35758b75/resource/d8fd7849-3330-4afa-9f90-7c89122afc87/download/adoptionparkv2.xlsx. Retrieved August 2019).

Table 2.0 List of local newspapers and property news which highlight park adoption programme in Kuala Lumpur

\begin{tabular}{|c|c|c|c|}
\hline No. & Title & Date & Link \\
\hline & General & & \\
\hline 1 & Bank to adopt city park & 21 April 2012 & $\begin{array}{l}\text { https://www.thestar.com.my/news/community/2012/04/21/bank-to-adopt- } \\
\text { city-park/ }\end{array}$ \\
\hline 2 & (NST) Standard Chartered unveils adopted park in the city & 27 Sept 2012 & $\begin{array}{l}\text { http://malaysiaretailnews.blogspot.com/2012/09/nst-standard-chartered- } \\
\text { unveils-adopted.html }\end{array}$ \\
\hline 3 & DBKL urges private sector to adopt the city's green spaces & 15 June 2015 & $\begin{array}{l}\text { https://www.thestar.com.my/metro/community/2015/06/15/park-your- } \\
\text { interest-dbkl-urges-private-sector-to-adopt-citys-green-spaces-as-it- } \\
\text { struggles-to-maintain }\end{array}$ \\
\hline 4 & Trees Planting \& Parks Adoption for KL Programme & 2017 & http://yahijau.com/trees-planting-parks-adoption-under-epp-6-greener-kl/ \\
\hline 5 & Greening KL with more pocket parks & 26 June 2015 & http://www.focusmalaysia.my/Assets/greening-kl-with-more-pocket-parks \\
\hline 6 & $\begin{array}{l}\text { DBKL and Think City Sdn. Bhd to transform park spaces } \\
\text { around Kuala Lumpur City Center }\end{array}$ & 18 March 2016 & $\begin{array}{l}\text { https://www.iproperty.com.my/news/dbkl-and-think-city-sdn-bhd-to- } \\
\text { transform-park-spaces-around-kuala-lumpur-city-center/ }\end{array}$ \\
\hline 7 & Senarai Adoption Park di Kuala Lumpur & N.A & $\begin{array}{l}\text { http://www.data.gov.my/data/ms_MY/dataset/senarai-adoption-park-di- } \\
\text { kuala-lumpur }\end{array}$ \\
\hline & Laman@ Eco Sky & & \\
\hline 1 & Eco Sky & N.A & http://www.constructionplusasia.com/eco-sky/ \\
\hline 2 & Laman@ Eco Sky officially opens & 20 Aug 2015 & https://ecoworld.my/press-release/laman-eco-sky-officially-opens/ \\
\hline 3 & $\begin{array}{l}\text { Eco Sky enjoys over } 70 \% \text { take-up since November } 2013 \\
\text { launch }\end{array}$ & 21 Aug 2015 & $\begin{array}{l}\text { https://www.edgeprop.my/content/eco-sky-enjoys-over-70-take- } \\
\text { november-2013-launch }\end{array}$ \\
\hline 4 & EcoWorld launches public park after RM1mil upgrade & 25 Aug 2015 & $\begin{array}{l}\text { https://www.thestar.com.my/metro/community/2015/08/25/preserving- } \\
\text { citys-greenery-ecoworld-launches-public-park-after-rm1 mil-upgrade }\end{array}$ \\
\hline 5 & Serah rizab hijau kepada DBKL & 5 Sept 2015 & https://www.hmetro.com.my/node/75263 \\
\hline 1 & $\begin{array}{l}\text { Kuala Lumpur Metropolis } \\
\text { Naza TTDI To Spend Rm20 Million For The Adoption Of } \\
\text { Metropolis Park At KI Metropolis Under Greener KI Initiative }\end{array}$ & 28 April 2017 & $\begin{array}{l}\text { http://www.naza.com.my/naza-ttdi-to-spend-rm20-million-for-the- } \\
\text { adoption-of-mertopolis-park-at-kl-metropolis-under-greener-kl-initiative/ }\end{array}$ \\
\hline 2 & $\begin{array}{l}\text { RM20mil Metropolis Park planned for the city } \\
\text { Read more at }\end{array}$ & 4 April 2017 & $\begin{array}{l}\text { https://Www.Thestar.Com.My/News/Nation/2017/04/04/Rm20mil- } \\
\text { Metropolis-Park-Planned-For-The-City }\end{array}$ \\
\hline 3 & $\begin{array}{l}\text { Naza TTDI to spend RM20m for KL Metropolis' Greener KL } \\
\text { initiative }\end{array}$ & 3 April 2017 & $\begin{array}{l}\text { https://www.nst.com.my/news/2017/04/226794/naza-ttdi-spend-rm20m- } \\
\text { kl-metropolis-greener-kl-initiative }\end{array}$ \\
\hline 4 & $\begin{array}{l}\text { Naza TTDI expects } 80 \% \text { of MET } 1 \text { to be sold by the end of } \\
\text { this year }\end{array}$ & 3 April 2017 & $\begin{array}{l}\text { https://www.theedgemarkets.com/article/naza-ttdi-expects-80-met-1-be- } \\
\text { sold-end-year }\end{array}$ \\
\hline $\begin{array}{l}5 \\
6\end{array}$ & $\begin{array}{l}\text { KL Metropolis } \\
\text { KL Metropolis poised to set a new bar }\end{array}$ & $\begin{array}{l}\text { N.A } \\
5 \text { April } 2019\end{array}$ & $\begin{array}{l}\text { https://www.nazattdi.com/project/portfolio-item/kl-metropolis-m/ } \\
\text { https://www.nst.com.my/property/2019/04/476528/kl-metropolis-poised- } \\
\text { set-new-bar }\end{array}$ \\
\hline
\end{tabular}

Source: Various sources listed under link above .

Table 3.0 Summary analysis of Park Adoption Programme at Laman@EcoSky and Metropolis Park Kuala Lumpur

\begin{tabular}{|c|c|c|c|c|c|c|c|c|c|c|c|c|c|}
\hline \multirow{2}{*}{$\begin{array}{l}\mathrm{N} \\
0 \\
.\end{array}$} & \multirow{2}{*}{$\begin{array}{l}\text { Spons } \\
\text { ored } \\
\text { by }\end{array}$} & \multirow{2}{*}{$\begin{array}{l}\text { Adopted } \\
\text { Park }\end{array}$} & \multicolumn{3}{|c|}{ Sponsorship Details } & \multirow{2}{*}{$\begin{array}{l}\text { Si } \\
\text { ze }\end{array}$} & \multirow{2}{*}{$\begin{array}{l}\text { Spons } \\
\text { orship } \\
\text { Allocat } \\
\text { ion } \\
\text { (RM) }\end{array}$} & \multirow{2}{*}{$\begin{array}{l}\text { Public- } \\
\text { Private } \\
\text { Partnership }\end{array}$} & \multirow{2}{*}{$\begin{array}{l}\text { Objectives of } \\
\text { Park Adoption }\end{array}$} & \multicolumn{3}{|c|}{ Benefits and Returns } & \multirow[b]{2}{*}{ Park Adopters } \\
\hline & & & Start & End & $\begin{array}{l}\text { Dura } \\
\text { tion }\end{array}$ & & & & & $\begin{array}{l}\text { Kuala } \\
\text { City } \\
\text { (DBKL) }\end{array}$ & $\begin{array}{r}\text { Lumpur } \\
\text { Hall }\end{array}$ & $\begin{array}{l}\text { Local } \\
\text { Residents }\end{array}$ & \\
\hline
\end{tabular}


Abdullah, J. et.al. / $8^{\text {th }}$ AcE-Bs2019Langkawilsland, Malaysia 18-19 Dec 2019 / E-BPJ, 4(12), Dec. 2019 (pp.193-201)

\begin{tabular}{|c|c|c|c|c|c|c|c|c|c|c|c|c|}
\hline 1 & $\begin{array}{l}\text { Eco } \\
\text { Sky } \\
\text { Devel } \\
\text { opme } \\
\text { nt } \\
\text { Sdn. } \\
\text { Bhd. }\end{array}$ & $\begin{array}{l}\text { Laman } \\
\text { @EcoSk } \\
\text { y }\end{array}$ & $\begin{array}{l}1^{\text {st }} \\
\text { April } \\
2015\end{array}$ & $\begin{array}{l}31^{\text {st }} \\
\text { Marc } \\
h \\
2018\end{array}$ & $3+2$ & $\begin{array}{l}3 \\
\text { ac } \\
\text { re }\end{array}$ & $\begin{array}{l}1 . \text { RM } \\
1 \\
\text { million } \\
\text { for } \\
\text { upgrad } \\
\text { ing } \\
2 . \text { RM3 } \\
\text { Million } \\
\text { for } \\
\text { infrastr } \\
\text { ucture } \\
\text { and } \\
\text { facilitie } \\
\text { s }\end{array}$ & $\begin{array}{l}\text { Federal } \\
\text { Territory } \\
\text { Ministry } \\
\text { (EPP6)- } \\
\text { DBKL- } \\
\text { EcoWorld } \\
\text { `EPP6- } \\
\text { Entry Point } \\
\text { Project } \\
\text { Greener } \\
\text { Kuala } \\
\text { Lumpur }\end{array}$ & $\begin{array}{l}\text { 1. To foster } \\
\text { city green } \\
\text { spaces } \\
\text { 2. Elevate the } \\
\text { quality of life of } \\
\text { the local } \\
\text { community } \\
\text { and future } \\
\text { residents } \\
\text { 3. Protect and } \\
\text { preserve the } \\
\text { environment }\end{array}$ & 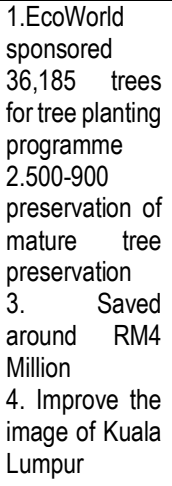 & $\begin{array}{l}\text { Survey on park } \\
\text { user's } \\
\text { satisfaction } \\
\text { was conducted } \\
\text { by DBKL (See } \\
\text { findings) }\end{array}$ & $\begin{array}{l}\text { 1. Increase } \\
\text { property value } \\
\text { 2. Improve the } \\
\text { image and } \\
\text { identity of the } \\
\text { neighbourhood } \\
\text { 3. The selling } \\
\text { point for Eco } \\
\text { Sky } \\
\text { Development }\end{array}$ \\
\hline 2 & $\begin{array}{l}\text { NAZA } \\
\text { TTDI } \\
\text { Sdn. } \\
\text { Bhd. }\end{array}$ & $\begin{array}{l}\text { Plot 8, } \\
\text { Kuala } \\
\text { Lumpur } \\
\text { Metropol } \\
\text { is City }\end{array}$ & $\begin{array}{l}\text { No } \\
\text { infor } \\
\text { mati } \\
\text { on }\end{array}$ & $\begin{array}{l}\text { No } \\
\text { infor } \\
\text { mati } \\
\text { on }\end{array}$ & $\begin{array}{l}15 \\
\text { year } \\
\mathrm{s}\end{array}$ & & $\begin{array}{l}1 . \\
\text { RM20 } \\
\text { Million }\end{array}$ & $\begin{array}{l}\text { Federal } \\
\text { Territory } \\
\text { Ministry } \\
\text { (EPP6)- } \\
\text { DBKL- } \\
\text { Naza TTDI } \\
\text { (Sdn Bhd.) } \\
\text { *EPP6- } \\
\text { Entry Point } \\
\text { Project } \\
\text { Greener } \\
\text { Kuala } \\
\text { Lumpur }\end{array}$ & $\begin{array}{l}\text { 1. To provide a } \\
\text { green lung for } \\
\text { Kuala Lumpur } \\
\text { Metropolis } \\
\text { 2. To improve } \\
\text { public health } \\
\text { 3.Community' } \\
\text { s recreational } \\
\text { space } \\
\text { 4.Sustainabilit } \\
\text { y and energy } \\
\text { efficiency }\end{array}$ & $\begin{array}{l}\text { 1.Naza } \\
\text { sponsored and } \\
\text { planted 50,000 } \\
\text { trees } \\
\text { 2. Saved } \\
\text { around RM20 } \\
\text { Million } \\
\text { 3. Naza } \\
\text { improved } \\
\text { connectivity } \\
\text { MET3 and } \\
\text { MITEC } \\
\text { (parkway and } \\
\text { LRT-MRT) }\end{array}$ & $\begin{array}{l}\text { User's } \\
\text { satisfaction not } \\
\text { yet conducted }\end{array}$ & $\begin{array}{l}\text { 1.Increase } \\
\text { property value } \\
\text { 2. Improve the } \\
\text { image and } \\
\text { identity of the } \\
\text { neighbourhood } \\
\text { 3. The selling } \\
\text { point for Naza } \\
\text { TTDI } \\
\text { Development }\end{array}$ \\
\hline
\end{tabular}

Source: Local newspaper reports from 2012-2019

\subsection{Findings and Discussion}

This part highlights four significance findings from the data analysis, which are: Public-private partnership, objectives of park adoption, sponsorship details (size of park and sponsorship allocation) and benefits and returns.

\subsection{Public-private partnership}

There are several neighbourhood parks in Kuala Lumpur which have been built with excellent facilities that are being neglected and falling into disrepair. Vandalism and poor maintenance have been identified as significant contributors for the abandoned public parks, although a great deal of money has been spent for landscaping and putting other facilities for park users (Aziz, N.A.A. 2012; Ayegi. A. and Ujang. N. 2014; Mansor et al., 2019). Due to limited budget to manage a sizeable coverage of urban park, DBKL is struggling to maintain public parks in the city. The EPP 6 (Greener $\mathrm{KL}$ ) which is one of the nine EPPs, is indeed pivotal to achieving the Greater Kuala Lumpur aspiration. Thus, DBKL urges corporate and private agencies to carry the Greener Kuala Lumpur Initiatives by participating in the park adoption programmes (Nair, 2015). The adoption of the Kuala Lumpur Metropolis Park by Naza TTDI and Laman @ Eco Sky by Eco Sky Development Sdn. Bhd programme demonstrates their proactive support for the Greener Kuala Initiatives. This is an excellent example of public-private partnership in park maintenance and management.

\subsection{Objectives of Park Adoption}

The main idea behind the Greener Kuala Lumpur Initiatives is not just promoting the novelty of sustainability; it is also paving the way for a clean environment and greener metropolis (Kanniah, K.D. 2017; Ismail.S.M et al., 2018). For the Laman @ Eco Sky, the park adopter has identified three objectives: [1] To foster city green spaces; [2] To elevate the quality of life of the local community and future residents; and [3] To protect and preserve the environment (Nathan, 2015). These objectives reflect the awareness of the park adopter in prioritizing both healthy community and environment.

In contrast with the Eco Sky Development Sdn Bhd, Naza TTDI had adopted slightly a bigger park located next to the Malaysia International Trade and Exhibition Centre (MITEC). The five acres park has five objectives which are: [1] To promote sustainability and energy efficiency; [2] To provide green lungs for the Kuala Lumpur Metropolis; [3] To improve public health; [4] To offer vibrant and lush green community recreational space, and [5] To inject functional linkages and transition space between MITEC and Metropolis Park (Farah Adilla, 2017; Kathy.B 2019). The five objectives set out by Naza are also in line with those at Laman @Eco Sky. These objectives are in line with good city planning practices of environment and community sustainability. 


\subsection{Sponsorship Details}

The 3-acre green reserve of Laman@Eco Sky adjacent to Taman Wahyu was officially handed over to DBKL in 2015. This park was adopted by EcoWorld for a $3+2$ year contract started from the 1st April 2015 until 31st March 2018. The developer had allocated RM1 million for upgrading works and RM3 million for additional facilities in the area, which includes building a new covered walkway connecting Eco Sky to the Taman Wahyu KTM station (Nathan, 2015). While the upgrading landscapes help to rejuvenate the local community's public health, the installation of the covered walkway improved connectivity between Taman Wahyu and Laman@EcoSky (EcoWorld, 2015).

The adoption of the 5 acres of Kuala Lumpur Metropolis Park shows a mutually beneficial way to significantly improve the quality of green public spaces that can be enjoyed by the public. Naza TTDI will manage RM20 million for upgrading and maintaining the park over a period of 15 years of adoption (Naza TTDI, 2017). Terrace garden, amphitheatre, jogging and bicycle track, playground are examples of facilities offered in this lush natural area which also promote a greener and healthy modern lifestyles.

\subsection{Benefits and Returns}

Land-use changes, degradation of environmental qualities, and establishment of multifunctional green infrastructures are a significant challenge for the City of Kuala Lumpur (Nor Akmar et al., 2011). Reduction of a yearly budget would accelerate the problem in urban public parks maintenance (Chiesura, 2004). Thus, the Park adoption programmes under the Greener Initiatives undoubtedly is beneficial for DBKL in transforming the city of Kuala Lumpur into a healthier and greener metropolis. Hence, the total of RM24 million allocated for the adopted parks has eased the burden of DBKL in upgrading and maintaining its public parks.

The adoption of the Laman@Eco Sky and Metropolis Park symbolize EcoWorld and Naza TTDI's proactive support for the Greener Kuala Lumpur Initiatives. Three hundred trees and ten different species of flowers will be planted at the Metropolis Park, while EcoWorld sponsored 36,185 trees for tree planting programme organized by DBKL. These efforts would support the EPP6 (Greener $\mathrm{KL}$ Initiatives) where trees planting will increase the green spaces per person from the current $11 \mathrm{~m} 2$ to that of $22 \mathrm{~m} 2$ which are the standard for liveable cities such as Vancouver (Yau et al., 2016).

Konijnendijk (2010) and Gulsrud (2015) had conducted research on the role of green spaces in promoting and branding the city. One of the significant findings from their research indicates that cities with good quality of green spaces often used this asset in marketing strategy targeted towards tourists and visitors. Through the park adoption programme, park adopters such as EcoWorld and Naza TTDI used the "green" and "sense' branding to promote their properties. The lush green and a well maintained Laman@Eco Sky and the oasis of the green lung with fully landscaped Kuala Lumpur Metropolis Park would become a significant selling point of their property development.

The public or residents nearby to the adopted park are enjoying the benefits of the programme. Based on the observation done by the EcoSky, it is evident that a high and consistent number of people visited Laman@EcoSky from the first week to the fourth week of August 2016 and from the first to the second week of September 2016.

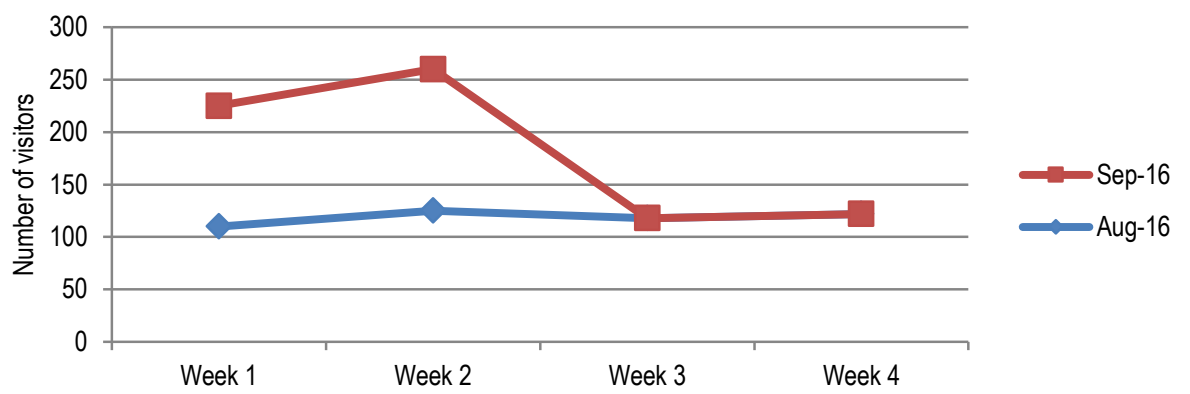

Figure 2.0 Statistic on the Number of Visitors to Laman@EcoSky in August and September 2016 Source: EcoSky

From the survey done by DBKL in 2016, people are visiting and using the park for numerous usage and reasons. Majority of respondents use the park for recreational activities $(40 \%)$, while the others use it for the other purposes such as passing by or as a medium of connection from one point to another $(20 \%)$, resting $(18 \%)$, sight-seeing $(14 \%)$ and as a meeting point $(8 \%)$. This shows that the adopted park managed to play its various roles and benefits the public. The survey likewise revealed that in general, $94 \%$ of the respondents are delighted with Laman@EcoSky.

The park's design and the original purposes of the park can be considered as successful and very much enjoyed by the users. This can be ascertained by the satisfaction level of the users in these two attributes, besides the other elements, as shown in Graph 2 and Graph 3 below. The period of time spent by the respondents at the park and the frequency of their visit also are testaments that the park is recurrently used and benefitted them significantly, where majority of the respondents (46\%) spend 1-2 hours at the park per visit, and $14 \%$ of them even spend more than 2 hours at the park per visit. In term of the frequency, $16 \%$ of the respondents in average visit the park more than ten times in a month, which demonstrates the high regularity of the park's usage. 


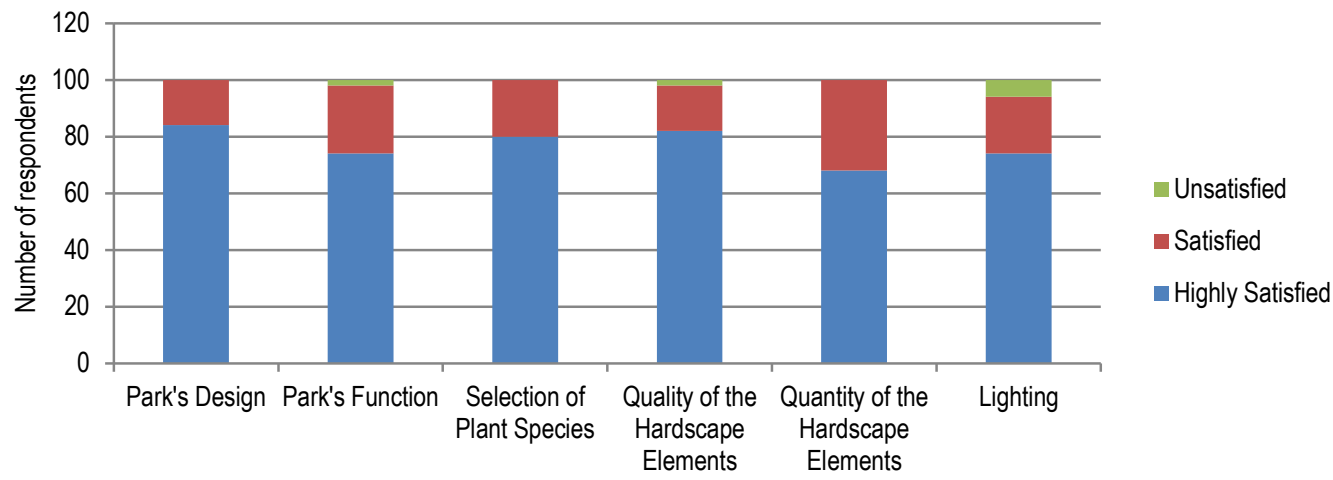

Figure 3.0 Summary on the Users' Satisfaction Level on the Physical Aspects of Laman@EcoSky Source: DBKL (2016)

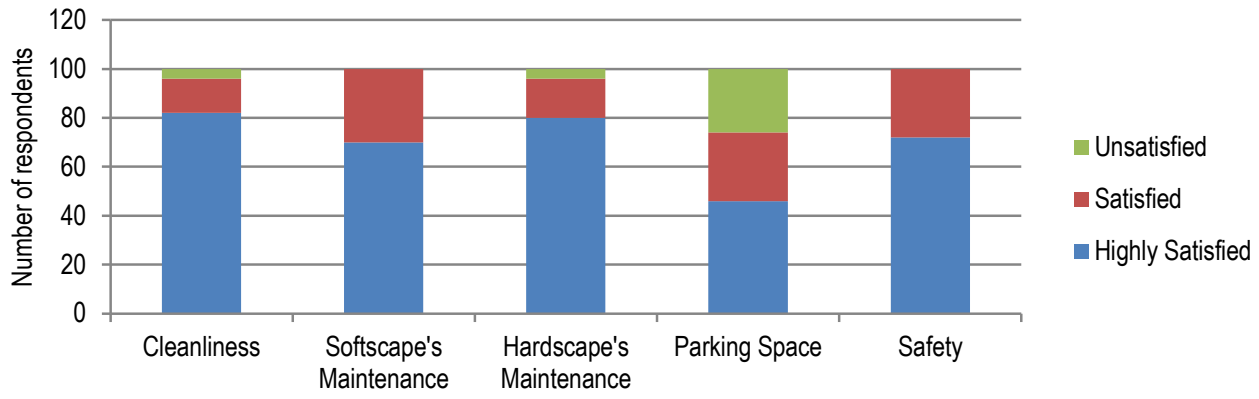

Figure 4.0 Summary on the Users' Satisfaction Level on the Services Aspects of Laman@EcoSky Source: DBKL (2016)

Based on the survey, it can be seen that the parks goers are very contented with the services of the park. They can experience a clean, well maintained, safe park while it is still in the adoption period. Only the parking space attribute recorded some unsatisfactory responses from the users, where $26 \%$ of them feel that the parking space is insufficient. However, considering the park is actually just a pocket park, and developed mainly for the nearby residents, it is understandable that the parking space was placed in limited number beside the restricted space of land.

\subsection{Limitation of Study}

There are some limitations in conducting this study. Lack of literature on the park adoption topic caused a little problem in the attempt to understand further, explain and elaborate on the subject. Besides, the data availability and accessibility are also restricted, especially on the budgeting and government funding, which are private and confidential. Thus, less analysis was able to be done on the monetary returns to the adopters and the amount of money that can be saved by the government by having this programme. Moreover, $\mathrm{KL}$ Metropolis Park is yet to be completed. Therefore the user's satisfactory study for that park cannot be conducted, which are supposed to be analysed and compared with that of Laman@EcoSky.

\subsection{Conclusion and Recommendations}

The concept of Adopt-A-Park has received much recognition and widely practised in many big cities, including the City of Kuala Lumpur. This research reveals the innovative idea and practice of the park adoption programme, which has been implemented through the CSR programme. Significance findings from this research irradiate how the government aspiration, such as the ETP and Greener Kuala Lumpur could be disseminated and materialized via the partnership between DBKL, corporate agencies and property developers.

The Malaysian Prime Minister, Tun Dr Mahathir Mohammad, in his speech at the Sustainable Development Goals (SDGs) Summit 2019 in New York in September 2019, highlights that Malaysia is making good progress on SDGs and seeks to accomplish all the goals ratified by the United Nations. Results from this study suggest that the benefits and returns of the Adopt-A-Park Programme validate DBKL's commitments towards promoting and achieving SDG3: Good Health and Well-being; SDG11: Sustainable Cities and Communities and SDG13: Climate Action.

The survey done on the park users' satisfaction at Laman @EcoSky shows that the lighting is the attribute that the users are most unsatisfied within the term of the physical aspect, compared with parking space for the services aspect. Therefore, in the future, the 
design of these two aspects should be given more attention and improvement, so that it can benefit and fulfil the needs of the parks' users.

The two case studies of the park adoption in this study are located in the vicinity of middle and upper-income neighbourhoods. Vandalism and poorly maintained facilities have become prominent issues of the B40 neighbourhood parks, in which local government is very much aware. Hence, in the Malaysia Budget 2020 proposals, much attention has been paid to improve the quality of life of the B40 group. In this context, DBKL should urge more active involvement from corporate agencies and private limited companies (PLCs) to extend their park adoption programme to parks near B40 neighbourhoods.

The central theme of the CSR programme is twofold: To improve the community's quality of life and quality of the environment. As mentioned in the limitation of the study, although the selected CSR programmes organized by DBKL were captured in the local newspapers, the data is still not well-publicized and inaccessible by the public. Thus, it is hoped than DBKL would disseminate more findings of its projects to the public. Findings of this study provide a good platform for other researchers to conduct in-depth research on park adoption as well as other CSR programmes.

\section{References}

Akmar, C.C. Konijnendijk, M. Sreetheran, and K. Nilsson. (2011). Greenspace Planning and Management in Klang Valley, Peninsular Malaysia, Arboriculture and Urban Forestry, 37(3), 99-107.

Ayeghi, A. and Ujang, N. (2014). The impact of physical features on user attachment to Kuala Lumpur, 3(3), 44-59.

Aziz, N.A.A. (2012). Green space use and management in Malaysia, Forest and Landscape Research, 51, 1-60.

Burnett, G.W. \& Harrington L.M.B. (1994). Early national park adoption in sub-Saharan Africa, Society \& Natural Resources, 7:2, 155-168. https://doi $10.1080 / 08941929409380853$

Chiesura, A. (2004). The role of urban parks for the sustainable city, Landscape and Urban Planning, 68(1), 129-138. http://dx.doi.org/10.1016/j.landurbplan.2003.08.003 DBKL. (2016). Pembentangan kajian penilaian outcome projek Greener KL, Kementerian Wilayah Persekutuan.

EcoWorld (2015). https://ecoworld.my/press-release/ecoworld-signs-agreement-with-dbkl-to-adopt-public-park-developer-commits-rm1million-for-upgrading-works-of-3acre-green-reservel

Farah, A. (2017). Naza TTDI to spend RM20m for KL Metropolis' Greener KL initiative, New Straits Times. https://www.nst.com.my/news/2017/04/226794/naza-ttdispend-rm20m-kl-metropolis-greener-kl-initiative

Gulsrud, N. (2015). The role of green space in city branding: an urban governance perspective.

Ismail.S.M et al. (2018). Going for green cities: the role of urban and peri-urban forestry in creating the ambience of the liveable city in Malaysia, Handbook of Sustainability Science and Research, 401-417. https://link.springer.com/chapter/10.1007/978-3-319-63007-6_24

Jahncke, H., Hygge, S., Halin, N., Green, A. M., \& Dimberg, K. (2011). Open-plan office noise: Cognitive performance and restoration. Journal of Environmental Psychology, 31(4), 373-382. https ://doi.org/10.1016/j.jenvp .2011.07.002.

Jepson, P. \& Whittaker, R.J. (2002). Histories of Protected Areas: Internationalisation of Conservationist Values and their Adoption in the Netherlands Indies (Indonesia), Environment and History, 8(2), 129-172. https://doi.org/10.3197/096734002129342620

Kanji, R., \& Agrawal, R. (2019). Building a society conducive to the use of corporate social responsibility as a tool to develop disaster resilience with sustainable development as the goal: an interpretive structural modelling approach in the Indian context, Asian Journal of Sustainability and Social Responsibility, 4(1). https://doi.10.1186/s41180-019-0025-7

Kanniah, K.D. (2017). Quantifying green cover change for sustainable urban planning: a case of Kuala Lumpur, Malaysia, Malaysia Sustainable Cities Program, Working Paper Series. https://scienceimpact.mit.edu/sites/defaultffiles/documents/Kanniah.pdf

Kathy, B. (2019). KL Metropolis poised to set a new bar, New Straits Times. https://www.nst.com.my/property/2019/04/476528/kl-metropolis-poised-set-new-bar

Konijnendijk, C. (2010). Green cities, competitive cities - promoting the role of green space in city branding.

Lu, J.Y., and Castka, P. (2009). Corporate social responsibility in Malaysia -experts' views and perspectives, Corporate Social Responsibility and Environmental Management, 16(3), 146-154. https://doi_10.1002/csr.184

Mansor, M., Zakariya, K., \& Harun, N.Z. (2019). Challenges on use of recreational parks in Kuala Lumpur, Journal of Construction in Developing Countries, 24(1): 141162. https://doi.org/10.21315/jcdc2019.24.1.8

Mohd. Nasir, N. E., Jasni, N.S., Mohd Sallem, N.R. \& Aziz, N.F. (2015). Corporate social responsibility: an overview from Malaysia, Journal of Applied Environmental and Applied Sciences.

Nathan, Y.T. (2015). EcoWorld launches public park after RM1mil upgrade, The Star. https://www.thestar.com.my/metro/community/2015/08/25/preserving-citysgreenery-ecoworld-launches-public-park-after-rm1mil-upgrade\#E70OD6cijyFAF2RJ.99

Naza TTDI (2017). http://www.naza.com.my/naza-ttdi-to-spend-rm20-million-for-the-adoption-of-mertopolis-park-at-kl-metropolis-under-greener-kl-initiative/ 
Oseland, N. (2009). The impact of psychological needs on office design. Journal of Corporate Real Estate, 11(4), 244-254. https ://doi.org/10.1108/14630 01091 10067 38

Race, D. \& Curtis, A. (2007). Adoption of farm forestry in Victoria: linking policy with practice, Australasian Journal of Environmental Management, 14(3), 166-178. http://www.eianz.org/index.cfm?objectid=032DC1DF-65BF-EBC1-22D6F697C5624CAD

Ramasamy B \& Ting HW. (2004). A comparative analysis of corporate social responsibility awareness: Malaysian and Singaporean firms, The Journal of Corporate Citizenship 13, 109-123.

Rashid MZA \& Ibrahim S. (2002). Executive and management attitudes towards corporate social responsibility in Malaysia. Corporate Governance, 2, 10-16.

Thompson P, Zakaria Z. (2004). Corporate social responsibility reporting in Malaysia: progress and prospects. The Journal of Corporate Citizenship, 13, 125-136.

Wan Fauzi, Z.H. (2015). Eco Sky enjoys over 70\% take-up since the November 2013 launch, EdgeProp. https://www.edgeprop.my/content/eco-sky-enjoys-over-70-takenovember-2013-launch

Wong, J. (2015). Greening KL with more pocket parks, Focus Malaysia. http://www.focusmalaysia.my/Assets/greening-kl-with-more-pocket-parks

PEMANDU (2012). Greater Kuala Lumpur/ Klang Valley, Economic Transformation Program (ETP). http://etp.pemandu.gov.my/Greater_Kuala_Lumpur_Klang_Valley@-Greater_Kuala_Lumpur-s-Klang_Valley.aspx

Wang, B., \& Adolphe, L. (2012). Spirit of place in the science park. Take ZJ Inno-Park as an example. In Proceedings of the international congress on ambiences (551556).

Yau et al. (2016). Greater Kuala Lumpur as a smart city: A case study on technology opportunities, 2016 8th International Conference on Knowledge and Smart Technology, KST 2016, 96-101. https://doi.org/10.1109/KST.2016.7440496

Zhang, Y. H. (2002). A developing economy-oriented model for science park management. Doctor of Philosophy thesis. 